\title{
ANALISIS KELAYAKAN FINANSIAL BUDIDAYA LEBAH MADU DI DESA KUAPAN KECAMATAN TAMBANG KABUPATEN KAMPAR (Kasus Usaha Madu "Mekar Sari")
}

\author{
ILMA SATRIANA DEWI ${ }^{\text {a) }}$ \\ a) Program Studi Agribisnis, Fakultas Pertanian, Universitas Islam Riau, Pekanbaru, Riau, Indonesia. \\ email: ilmasatrianadewi@agr.uir.ac.id
}

\begin{abstract}
ABSTRAK
Madu merupakan salah satu produk pertanian yang memiliki manfaat dan nilai ekonomi yang tinggi. Sebagian produksi madu yaitu sekitar 75\% masih bergantung pada hasil hutan. Sementara, luas kawasan hutan yang ada semakin berkurang jumlahnya sehingga juga berdampak pada penurunan produksi madu. Sebagian masyrakat sudah melakukan budidaya lebah madu untuk meningkatkan produksi. Namun, minat masyarakat masih sangat rendah karena kurangnya pengetahuan dan anggapan bahwa usaha tersebut tidak menguntungkan. Penelitian ini bertujuan untuk menganalisis harga pokok produksi dan kelayakan finansial usaha budidaya lebah madu. Analisis data menggunakan analisis deskriptif kuantitatif. Hasil penelitian menunjukkan bahwa harga pokok produksi adalah sebesar Rp 96.404,20/kg dengan persentase mark up yang diambil oleh peternak sebesar 64\%. Usaha madu "Mekar Sari" layak untuk dijalankan dengan nilai NPV sebesar Rp 121.239.464 (NPV > 0), IRR sebesar 74\% (IRR > 24\%), Net B/C ratio sebesar 2,1, BEP 71,31 kg dan PP selama 1 tahun 4 bulan 11 hari. Hasil analisis sensitivitas juga menunjukkan bahwa usaha madu "Mekar Sari" masih layak untuk dijalankan dengan perubahan parameter biaya operasional dan pendapatan sebesar $5 \%$.
\end{abstract}

Kata kunci: madu, harga pokok produksi, kelayakan finansial

\section{PENDAHULUAN}

Sebagian hasil madu yang ada di Indonesia sekitar 75\% diperoleh dari perburuan madu liar di hutan dengan hasil produksi berkisar 4000 ton per tahun (Kuntadi, 2008). Namun, jika dilihat dari sisi luas kawasan hutan

35 Analisis Kelayakan Finansial Budidaya Lebah Madu Di Desa Kuapan Kecamatan Tambang Kabupaten Kampar (Kasus Usaha Madu "Mekar Sari") 
terjadi penurunan luas hutan yang relatif tinggi. Dimana dari data yang diperoleh pada tahun 2014, luas kawasan hutan adalah sebesar 126,30 juta ha. Jumlah luas ini menurun jika dibandingkan dengan luas kawasan hutan pada tahun 2010 yaitu sebesar 136,88 juta ha (Kementerian Kehutanan, 2014). Berdasarkan data Dirjen BPDASPS tahun 2103, produksi madu di Indonesia hanya berkisar 2.000 ton per tahun. Jika dibandingkan dengan produksi madu pada tahun 2008 yaitu sebesar 4.000 ton per tahun, hal ini menunjukkan bahwa produksi madu mengalami penurunan yang cukup signifikan.

Pada tahun 2012, perdagangan madu di Indonesia juga mengalami defisit yang menunjukkan adanya kekurangan produksi yang tidak berimbang dengan potensi pasar yang ada di dalam negeri. Produksi madu yang semakin menurun dari tahun ke tahun tidak mampu memenuhi kebutuhan konsumen terhadap madu. Jika konsumsi madu di Indonesia diasumsikan sebesar 30gr/kapita/tahun, maka kebutuhan domestik terhadap madu berkisar 7.500 ton per tahun. Hal ini menunjukkan bahwa masih terdapat kekurangan produksi sebesar 5.500 ton per tahun. Sehingga, untuk mencukupi kebutuhan madu di Indonesia salah satu upaya yang bisa dilakukan adalah dengan melakukan kegiatan budidaya lebah madu.

Pengembangan usaha budidaya lebah madu perlu dilakukan mengingat adanya potensi yang cukup besar baik dari segi kebutuhan masyarakat maupun untuk keberlanjutan usaha budidaya lebah. Perlunya dilakukan pengembangan usaha budidaya lebah madu juga dapat dilihat dari adanya peluang yang cukup besar untuk usaha ini, mulai dari harga produk yang

Analisis Kelayakan Finansial Budidaya Lebah Madu Di Desa Kuapan Kecamatan Tambang Kabupaten Kampar (Kasus Usaha Madu "Mekar Sari") 
relatif tinggi, biaya produksi yang relatif lebih murah, pemeliharaan yang mudah dan kondisi alam yang mendukung.

Kabupaten Kampar merupakan salah satu sentra daerah penghasil madu di Provinsi Riau. Namun, usaha ini masih belum banyak dikenal oleh masyarakat umum. Hal ini didukung oleh data yang menyatakan bahwa lebih dari $90 \%$ produk lebah madu lebih banyak dinikmati oleh masyarakat di luar Kabupaten Kampar. Sedangkan masyarakat di Kabupaten Kampar sendiri lebih memilih madu yang berasal dari luar. Produksi madu di kabupaten Kampar secara keseluruhan sudah mencapai 85 ton/tahun. Namun, jumlah ini merupakan hasil produksi madu dengan mengambil hasil madu atau dipanen dari pohon-pohon yang ada dihutan (sialang). Budidaya ternak lebah di Kampar sudah ada yang dilakukan dengan cara yang lebih modern yaitu menggunakan sarang yang terbuat dari kayu dengan bingkai sisiran sarang di dalamnya. Dengan cara yang lebih modern ini, tentunya diharapkan dapat memberikan hasil panen yang lebih tinggi dibandingkan hanya memanfaatkan hasil dari sarang lebah yang ada dihutan (sialang).

Selain dapat meningkatkan produksi, melakukan budidaya lebah madu juga dapat memberikan peluang untuk meningkatkan pendapatan masyarakat. Beberapa petani mengatakan bahwa modal yang di butuhkan untuk menjalankan usaha ini memang termasuk besar. Namun, pendapatan yang di peroleh pun terbilang besar. Untuk modal keseluruhan dengan 200 box koloni menghabiskan dana sekitar 21 juta untuk modal awal sementara untuk modal operasional menghabiskan dana sekitar 40 juta. Sementara untuk pendapatan yang di peroleh berkisar antara 80 - 90 juta / tahun dengan keuntungan bersih sekitar 50 juta/tahun atau 6 juta/bulan.

37 Analisis Kelayakan Finansial Budidaya Lebah Madu Di Desa Kuapan Kecamatan Tambang Kabupaten Kampar (Kasus Usaha Madu "Mekar Sari”) 
Beberapa masyarakat di Kecamatan Kampar Timur sudah menjalankan usaha ternak lebah madu (Apis cerana) dengan sistem modern. Namun, usaha ini belum berkembang dengan optimal. Hal ini disebabkan kurangnya pengetahuan dan keyakinan masyarakat setempat mengenai potensi usaha budidaya lebah madu. Sehingga, berdasarkan permasalahan di atas, maka dilakukan analisis finansial untuk melihat apakah usaha ini layak atau tidak untuk dijalankan. Selanjutnya, dapat dirumuskan beberapa pertanyaan antara lain, Berapa harga pokok produksi pada usaha budidaya lebah madu? Bagaimana kelayakan finansial usaha budidaya lebah madu? Berdasarkan beberapa uraian tersebut, maka tujuan yang ingin dicapai pada penelitian ini adalah (1) menganalisis harga pokok prodduksi usaha budidaya lebah madu ; dan (2) menganalisis kelayakan finansial usaha budidaya lebah madu.

\section{METODE PENELITIAN}

Lokasi penelitian dilakukan di Desa Kuapan yang dipilih secara purposive dengan pertimbangan lokasi ini merupakan madu yang diproduksi berasal dari usaha lebah madu yang dibudidayakan. Selain itu, usaha budidaya lebah madu yang dilakukan di daerah tersebut juga sudah berjalan cukup lama yaitu berkisar 18 tahun. Penelitian ini telah dilakukan pada Maret 2017 sampai Agustus 2017, dengan tahapan kegiatan meliputi penyusunan proposal penelitian, pengambilan data, pengolahan data, dan analisis data.

Responden penelitian adalah peternak sekaligus pemilik usaha budidaya lebah madu pada usaha budidaya madu "Mekar Sari". Dalam pengambilan responden ditentukan secara purposive (sengaja) dengan

38 Analisis Kelayakan Finansial Budidaya Lebah Madu Di Desa Kuapan Kecamatan Tambang Kabupaten Kampar (Kasus Usaha Madu "Mekar Sari") 
pertimbangan peternak yang dijadikan responden sudah melakukan sistem budidaya (bukan madu sialang).

Data yang dikumpulkan dalam penelitian ini terdiri dari data primer dan sekunder. Data primer meliputi karakteristik peternak usaha budidaya lebah madu (meliputi: umur, pendidikan, pengalaman berusaha, dan jumlah anggota rumah tangga). Selanjutnya, profil usaha budidaya lebah madu, meliputi luas lahan usaha dan status kepemilikan usaha, penggunaan input, produksi, harga, sarana produksi dan data lainnya yang dianggap penting. Data primer diperoleh melalui wawancara langsung dengan responden.

Selanjutnya, data sekunder dalam penelitian ini diperoleh dari instansi terkait, seperti: Badan Pusat Statistik (BPS) Kabupaten Kampar, Kantor Desa Kuapan serta data dari instansi lainnya yang diperlukan dalam penelitian ini. Data sekunder meliputi keadaan lokasi penelitian, luas areal, iklim, demografi, topografi Desa Kuapan.

Harga pokok produksi ditentukan dengan menggunakan persamaan berikut (Mulyadi, 1992):

$H p=\frac{B t+B v}{\sum M}$

Dimana:

$\mathrm{Hp}=$ harga pokok produksi $\operatorname{madu}(\mathrm{Rp} / \mathrm{kg})$

$\mathrm{Bt}=$ biaya tetap $(\mathrm{Rp} / \mathrm{th})$

$\mathrm{Bv}=$ biaya variabel $(\mathrm{Rp} / \mathrm{th})$

$\Sigma \mathrm{M}=$ jumlah madu yang dihasilkan ( $\mathrm{kg} / \mathrm{th})$

Analisis finansial yang dilakukan terdiri dari beberapa perhitungan yaitu analisis BEP, NPV, IRR, $\mathrm{PB}$, dan $\mathrm{B} / \mathrm{C}$ ratio. Perhitungan nilai BEP dapat digunakan rumus sebagai berikut (Pramudya dan Dewi, 1992):

39 Analisis Kelayakan Finansial Budidaya Lebah Madu Di Desa Kuapan Kecamatan Tambang Kabupaten Kampar (Kasus Usaha Madu "Mekar Sari”) 


$$
B E P=\frac{F C}{P-\frac{V C}{Q}}
$$

Keterangan:

$\mathrm{BEP}=$ Titik impas

$\mathrm{FC}=$ Biaya tetap usaha budidaya madu $(\mathrm{Rp} / \mathrm{th})$

$\mathrm{VC}=$ Biaya variabel usaha budidaya madu $(\mathrm{Rp} / \mathrm{th})$

$\mathrm{P}=$ Harga jual madu $(\mathrm{Rp} / \mathrm{kg})$

$\mathrm{Q}=$ Jumlah produksi madu $(\mathrm{kg})$

Untuk menghitung nilai NPV dapat digunakan rumus sebagai berikut (Gitinger, 1986):

$N P V=\sum_{t=1}^{t=n} \frac{M t-B t}{(1+i)^{t}}$

Keterangan :

$\mathrm{t}=1,2, \ldots \ldots, \mathrm{n}$

$\mathrm{n}=$ periode usaha budidaya madu (tahun)

$\mathrm{i}=$ tingkat suku bunga (diskonto)

$\mathrm{Mt}=$ penerimaan $($ benefit $)$ yang diperoleh pada tahun ke-t $(\mathrm{Rp})$

$\mathrm{Bt}=$ biaya $($ cost $)$ yang dikeluarkan pada tahun ke-t $(\mathrm{Rp})$

Nilai NPV memiliki arti:

1. Apabila NPV > 0, maka usaha budidaya lebah madu layak untuk dilaksanakan/ menguntungkan

2. Apabila NPV $=0$, maka usaha budidaya lebah madu impas antara manfaat dan biaya

40 Analisis Kelayakan Finansial Budidaya Lebah Madu Di Desa Kuapan Kecamatan Tambang Kabupaten Kampar (Kasus Usaha Madu "Mekar Sari") 
3. Apabila NPV < 0, maka usaha budidaya lebah madu tidak layak untuk dilaksanakan/ merugikan, karena manfaat lebih kecil dari 0 sehingga usaha tidak dapat dilaksanakan.

Untuk memperoleh hasil IRR dapat digunakan perhitungan dengan rumus sebagai berikut:

$$
\operatorname{IRR}=\sum_{t=1}^{t=n} \frac{M t-B t}{(1+i)^{t}}=0
$$

Keterangan :

$\mathrm{t}=1,2, \ldots ., \mathrm{n}$

$\mathrm{n}=$ jumlah periode usaha budidaya lebah madu (tahun)

$\mathrm{i}=$ tingkat bunga (diskonto)

$\mathrm{Mt}=$ manfaat $($ benefit $)$ yang diperoleh tiap tahun

$\mathrm{Bt}=$ biaya $($ cost $)$ yang dikeluarkan tiap tahun

Jika: IRR > suku bunga bank yang berlaku, maka usaha budidaya lebah madu layak untuk dijalankan

IRR < suku bunga bank yang berlaku, maka usaha budidaya lebah madu tidak layak untuk dijalankan

IRR = suku bunga bank yang berlaku, maka usaha budidaya lebah madu impas (tidak menguntungkan dan tidak rugi).

Rumus umum yang dapat digunakan untuk menghitung nilai payback period (PB) adalah sebagai berikut:

$$
P B=\left[t+\frac{b-c}{d-c}\right] \times 12
$$

Keterangan:

$\mathrm{t}=$ tahun terakhir dimana komulatif net cash belum mencapai initial investment

41 Analisis Kelayakan Finansial Budidaya Lebah Madu Di Desa Kuapan Kecamatan Tambang Kabupaten Kampar (Kasus Usaha Madu "Mekar Sari”) 
$\mathrm{b}=$ initial investment (modal awal) usaha budidaya lebah madu (Rp)

$\mathrm{c}=$ komulatif net cash inflow usaha budidaya lebah madu pada tahun ke $\mathrm{t}$ (Rp)

$\mathrm{d}=$ komulatif net cash inflow usaha budidaya lebah madu pada tahun ke $\mathrm{t}+1$ (Rp)

Jika masa pembayaran kembali dari suatu investasi yang diusulkan lebih pendek dari masa pembayaran maksimum, maka investasi terhadap usaha tersebut dapat diterima dan layak untuk dijalankan. Jika Jika masa pembayaran kembali dari suatu investasi yang diusulkan lebih panjang dari masa pembayaran maksimum, maka investasi terhadap usaha tersebut tidak dapat diterima dan tidak layak untuk dijalankan.

Untuk menghitung nilai $B / C$ ratio dapat digunakan rumus umum sebagai berikut (Gitinger, 1986):

$$
B / C^{\text {ratio }}=\frac{\sum_{t=1}^{t=n} \frac{M t}{(1+i)^{t}}}{\sum_{t=1}^{t=n} \frac{B t}{(1+i)^{t}}}
$$

Keterangan :

$\mathrm{t}=1,2, \ldots ., \mathrm{n}$

$\mathrm{n}=$ jumlah tahun usaha budidaya lebah madu (tahun)

$\mathrm{i}=$ tingkat bunga (diskonto) usaha budidaya lebah madu (\%)

$\mathrm{Mt}=$ manfaat (benefit) dari usaha budidaya lebah madu yang diperoleh tiap tahun $(\mathrm{Rp})$

$\mathrm{Bt}=$ biaya (cost) usaha budidaya lebah madu yang dikeluarkan tiap tahun (Rp)

42 Analisis Kelayakan Finansial Budidaya Lebah Madu Di Desa Kuapan Kecamatan Tambang Kabupaten Kampar (Kasus Usaha Madu "Mekar Sari") 
Jika: $\mathrm{B} / \mathrm{C}>1$, maka pengembalian investasi yang ditanamkan dapat kembali $\mathrm{B} / \mathrm{C}<1$, maka pengembalian investasi yang ditanamkan tidak dapat kembali

Analisis sensitivitas dilakukan dengan menghitung IRR, NPV, dan $B / C$ ratio pada beberapa skenario perubahan yang mungkin terjadi. Beberapa skenario yang dilakukan yaitu, 1) kenaikan dan penurunan biaya operasional usaha lebah, dan 2) kenaikan serta penurunan pendapatan usaha budidaya lebah. Persentase kenaikan atau penurunan pada skenario tersebut disesuaikan dengan rata-rata tingkat inflasi yaitu sebesar 5\%.

\section{HASIL DAN PEMBAHASAN}

Perhitungan Harga Pokok Produksi (HPP) madu "Mekar Sari" adalah sebesar Rp. 96.404,20/kemasan 1 kg. Sementara, harga jual yang ada pada tingkat produsen adalah sebesar Rp 150.000,00/kg. Berdasarkan harga yang diberlakukan peternak kepada konsumen, diperoleh pengambilan keuntungan (mark up) sebesar $64 \%$ dari harga pokok produksi. Dari harga jual tersebut, berarti keuntungan yang diterima peternak adalah sebesar $64 \%$ dari setiap unit produk yang terjual. Menurut Subanar (2001), besarnya mark up ditingkat produsen langsung ke konsumen sebesar 20\%, jika melalui agen atau pengecer mark up sebesar $40 \%$ dan bila pengecer menjual produk ke konsumen akhir mark up yang ditetapkan bisa mencapai $70 \%$.

Peternak menjual langsung madu berdasarkan permintaan konsumen, sehingga konsumen dapat langsung menerima produk/madu dari peternak tanpa adanya pedagang perantara. Mark up yang diambil oleh peternak lebih

43 Analisis Kelayakan Finansial Budidaya Lebah Madu Di Desa Kuapan Kecamatan Tambang Kabupaten Kampar (Kasus Usaha Madu "Mekar Sari") 
besar jika dibandingkan mark up yang seharusnya. Penetapan mark up yang cukup tinggi ini bisa dilakukan oleh peternak karena tidak adanya saluran pemasaran lain yang terlibat. Selain itu, di daerah penelitian hanya peternak madu "Mekar Sari" yang mampu memproduksi dan menjual madu kepada konsumen.

Metode untuk pengukuran kelayakan finansial usaha madu "Mekar Sari” dilakukan dengan beberapa perhitungan/analisis antara lain, perhitungan BEP, Net Present Value (NPV), Internal Rate of Return (IRR), Net Benefit Cost Ratio (B/C ratio) dan Payback Periode (PP). Pada dasarnya metode tersebut untuk membandingkan antara biaya investasi awal (initial investment) dengan arus kas bersih (Net Cash Flow) yang diterima selama masa pengusahaan budidaya lebah madu tersebut. Hasil rekapitulasi analisa kelayakan finansial disajikan pada Tabel 1.

Berdasarkan hasil perhitungan break event point (BEP) untuk budidaya lebah madu "Mekar Sari" diperoleh hasil BEP unit sebesar 71,31 kg. Jika ingin mencapai titik impas maka minimal peternak harus mempersiapkan 17 sampai 18 koloni lebah. Nilai tersebut menunjukkan banyaknya jumlah madu yang bisa menghasilkan titik impas bagi usaha tersebut. Jika usaha lebah madu ini hanya menghasilkan output (madu) sebanyak $71,31 \mathrm{~kg}$, maka usaha ini tidak mengalami kerugian ataupun tidak akan memperoleh keuntungan. Artinya, jika ingin memperoleh keuntungan maka peternak madu harus mampu menghasilkan output dengan jumlah lebih dari $71,31 \mathrm{~kg}$. Dan dari hasil penelitian yang dilakukan, hasil madu yang dapat diperoleh peternak madu sudah melebihi dari 71,31 kg yaitu

Analisis Kelayakan Finansial Budidaya Lebah Madu Di Desa Kuapan Kecamatan Tambang Kabupaten Kampar (Kasus Usaha Madu "Mekar Sari”) 
sebesar $800 \mathrm{~kg} /$ tahun. Hal ini juga mengindikasikan bahwa usaha tersebut dapat disimpulkan layak untuk dijalankan.

Tabel 1. Hasil Analisis Kelayakan Finansial Usaha Madu "Mekar Sari"

\begin{tabular}{clrr}
\hline No & \multicolumn{1}{c}{ Alat Analisis } & Hasil Analisis & \multicolumn{1}{c}{ Keterangan } \\
\hline 1 & BEP & $>71,31 \mathrm{~kg}$ & Layak \\
2 & $\begin{array}{l}\text { Net Present Value } \\
(\text { NPV })\end{array}$ & $74 \%$ & Layak \\
3 & $\begin{array}{l}\text { Internal Rate of } \\
\text { Return (IRR) } \\
4\end{array}$ & $\begin{array}{l}\text { Net Benefit Cost Ratio } \\
\text { (Net B/C) }\end{array}$ & 21.239 .464 \\
5 & Payback Periode & 1 tahun 4 bulan 11 hari & Layak \\
& & & Layak \\
\hline
\end{tabular}

Net Present Value (NPV), metode ini memperhatikan baik aliran kas netto (Net Cash Flow) yang memperhitungkan "Time Value Money" yaitu dengan adanya tingkat bunga (discount rate) yang ditetapkan sebesar $24 \%$ berdasarkan tingkat suku bunga pinjaman kredit yang berlaku di bank dan dengan asumusi tidak ada perubahan tingkat suku bunga selama konsesi. Analisa nilai NPV yang ditinjau adalah dari sisi investor, karena menganalisa investasi dari proyek. Dari Tabel 1 menunjukkan nilai NPV dengan nilai discount rate 24\% sebesar Rp 121.239.464 yang bernilai positif berarti usaha layak untuk dilaksanakan karena jumlahnya lebih besar dari nilai investasi. Nilai NPV tersebut juga menunjukkan bahwa usaha lebah madu ini dapat memberikan keuntungan sebesar Rp 121.239.464 selama 5 tahun menurut nilai waktu uang sekarang. NPV yang dihasilkan pada usaha madu "Mekar Sari” juga sejalan dengan hasil penelitian lainnya dengan jumlah NPV yang positif (NPV > 0) yaitu sebesar Rp 126.949 .659 pada tingkat DF 7\%. (Nurhasanah, 2007). Selanjutnya, hasil penelitian pada jenis usaha yang sama menghasilkan NPV sebesar Rp 228.945.600 pada tingkat DF 10\%

Analisis Kelayakan Finansial Budidaya Lebah Madu Di Desa Kuapan Kecamatan Tambang Kabupaten Kampar (Kasus Usaha Madu "Mekar Sari") 
(NPV > 0) (Yelin, 2008). Besar kecilnya nilai NPV juga tergantung pada biaya investasi dan DF masing-masing usaha. Namun, dengan nilai NPV yang positif (NPV > 0) sudah dapat menunjukkan bahwa suatu usaha dapat/layak dilaksanakan.

Internal Rate of Return (IRR), merupakan kriteria investasi yang bisa dipakai untuk mengukur persentase keuntungan dari proyek dalam mengembalikan pinjaman. Pada Tabel 1 terlihat nilai IRR sebesar 74\%. Artinya, usaha madu "Mekar Sari" mampu membayar tingkat bunga hingga mencapai 74\%. Nilai IRR ini lebih besar dari tingkat bunga (discount rate) yang digunakan yaitu 24\% (IRR > 24\%), sehingga dapat disimpulkan bahwa proyek layak untuk dilaksanakan. Hasil perhitungan IRR juga sebanding dengan hasil penelitian Adalina (2007) dimana terdapat nilai IRR sebesar 75\% untuk usaha madu Apis cerana. Besar kecilnya persentase IRR pada beberapa usaha madu tergantung dari tingkat bunga (DF) yang digunakan pada analisis finansial masing-masing usaha. Seperti pada usaha Lebah Madu Sari Bunga, hanya menunjukkan nilai IRR sebesar 10,70\% (Nurhasannah, 2007). Jika dibandingkan dengan usaha madu "Mekar Sari", nilai tersebut masih sangat kecil. Namun karena usaha Lebah Madu Sari Bunga hanya menggunakan DF sebesar $7 \%$ pada analisis finansialnya, sehingga usaha tersebut sudah dapat dikatakan layak untuk dilaksanakan.

Hasil analisis finansial usaha budidaya lebah madu "Mekar Sari" diperoleh nilai Net B/C ratio sebesar 2,1. Nilai tersebut menunjukkan bahwa setiap Rp 1 biaya yang dikeluarkan, maka akan menghasilkan keuntungan sebesar Rp 1,1. Hasil B/C ratio yang lebih besar dari 1, juga sejalan dengan hasil penelitian oleh Leonard (2008) dengan B/C ratio usaha madu Odeng

46 Analisis Kelayakan Finansial Budidaya Lebah Madu Di Desa Kuapan Kecamatan Tambang Kabupaten Kampar (Kasus Usaha Madu "Mekar Sari") 
sebesar 1,41 (layak) dan Yelin (2007) untuk usaha madu Apis cerana dengan $\mathrm{B} / \mathrm{C}$ ratio sebesar 1,39 (layak). Hal ini juga mengisyaratkan bahwa usaha budidaya lebah madu "Mekar Sari" layak untuk dijalankan.

Payback Periode dihitung untuk mengetahui berapa lama investasi yang ditanam pada usaha budidaya lebah madu "Mekar Sari” dapat kembali. Hasil analisis payback periode menunjukkan bahwa usaha ini membutuhkan waktu selama lebih kurang 1 tahun 4 bulan 11 hari sejak biaya investasi dikeluarkan (tahun 0) untuk mengembalikan biaya investasi sebesar Rp 108.588.900. Karena pengembalian investasi yang lebih cepat dari umur proyek/usaha (5 tahun), sehingga dapat disimpulkan bahwa usaha ini layak untuk dijalankan.

Analisis sensitivitas dilakukan untuk mengetahui parameter pokok yang diperkirakan mempunyai pengaruh signifikan terhadap kelayakan investasi. Beberapa parameter yang ditinjau adalah pendapatan, dan biaya operasional dengan skenario terjadi peningkatan maupun penurun pada parameter tersebut sebesar 5\% sesuai dengan tingkat inflasi. Untuk melihat pengaruh penurunan atau kenaikan paramater tersebut terhadap kelayakan usaha dapat dilihat dari perubahan hasil analisis NPV, IRR, dan B/C rationya. Adapun hasil perhitungan untuk analisis sensitivitas pada usaha budidaya lebah madu "Mekar Sari” dapat dilihat pada Tabel 2.

Tabel 2. Hasil Perubahan Parameter (Sensitivitas) pada Usaha Madu "Mekar Sari" di Desa Kuapan.

\begin{tabular}{|c|c|c|c|c|c|c|}
\hline \multirow{3}{*}{ No } & \multirow{3}{*}{$\begin{array}{l}\text { Alat } \\
\text { Analisis }\end{array}$} & \multicolumn{4}{|c|}{ Perubahan Parameter } & \multirow{3}{*}{$\begin{array}{l}\text { Sebelum } \\
\text { Perubahan }\end{array}$} \\
\hline & & \multicolumn{2}{|c|}{ Biaya Operasional } & \multicolumn{2}{|c|}{ Pendapatan } & \\
\hline & & Naik $5 \%$ & Turun 5\% & Naik 5\% & Turun 5\% & \\
\hline 1 & NPV & Rp113.299.977 & Rp129.178.951 & Rp156.302.324 & Rp125.798.080 & Rp121.239.464 \\
\hline 2 & IRR & $69 \%$ & $80 \%$ & $80 \%$ & $69 \%$ & $74 \%$ \\
\hline \multirow[t]{2}{*}{3} & $\mathrm{~B} / \mathrm{C}$ & 2 & 2 & 2 & 2 & 2,1 \\
\hline & 47 & $\begin{array}{l}\text { Analisis Kela } \\
\text { Kuapan Keca } \\
\text { Madu "Mekar }\end{array}$ & $\begin{array}{ll}\text { Jakan Finans } \\
\text { natan Tamba } \\
\text { Sari") }\end{array}$ & $\begin{array}{l}\text { ial Budidaya } \\
\text { ng Kabupater }\end{array}$ & $\begin{array}{l}\text { Lebah Mac } \\
\text { Kampar }\end{array}$ & $\begin{array}{l}\text { Di Desa } \\
\text { asus Usaha }\end{array}$ \\
\hline
\end{tabular}


Dari hasil perhitungan/analisis tersebut, dapat kita lihat bahwa meskipun terjadi kenaikan ataupun penurunan pada biaya operasional dan pendapatan sebesar $5 \%$, terdapat perubahan nilai baik pada NPV, IRR, B/C ratio nya maupun payback periode (PP).

Perubahan yang cukup signifikan terjadi pada skenario kenaikan pendapatan sebesar 5\% dengan NPV yaitu Rp 156.302.324, IRR sebesar $80 \%$, dan B/C ratio sebesar 2. Meskipun terjadi perubahan pada nilai NPV, IRR, maupun $\mathrm{B} / \mathrm{C}$ ratio dengan beberapa skenario tersebut, secara keseluruhan dapat disimpulkan bahwa usaha lebah madu "Mekar Sari" masih layak untuk dilakukan. Hal ini disebabkan dari nilai NPV yang menunjukkan jumlah positif, nilai IRR yang lebih besar dari tingkat suku bunga, $\mathrm{B} / \mathrm{C}$ ratio yang lebih besar dari 1 pada masing-masing perubahan parameter. Berbeda dengan hasil penelitian oleh Nurhasanah (2007) yang menunjukkan bahwa pada jenis usaha yang sama yaitu budidaya lebah madu Apis cerana, dimana usaha ini menjadi tidak layak (sangat sensitif) pada perubahan penurunan penerimaan sebesar 5\%. Perubahan yang terjadi adalah nilai NPV menjadi negatif (Rp -14.632.084) dan nilai IRR yang lebih kecil atau di bawah tingkat suka bunga yang berlaku $(6,56 \%<7 \%)$.

\section{KESIMPULAN}

1. Harga pokok produksi dari hasil analisis diperoleh sebesar $\mathrm{Rp}$ 96.404,20/kg. Produsen (peternak) mengambil mark up (keuntungan) lebih kurang sekitar 64\% dari harga pokok produksi. Peternak dapat menetapkan mark up yang cukup tinggi ini, karena di daerah penelitian

Analisis Kelayakan Finansial Budidaya Lebah Madu Di Desa Kuapan Kecamatan Tambang Kabupaten Kampar (Kasus Usaha Madu "Mekar Sari") 
hanya terdapat 1 produsen madu dan langsung menjual madu kepada konsumen sehingga tidak ada pedagang perantara lainnya yang terlibat.

2. Hasil analisis kelayakan finasial usaha madu "Mekar Sari" menunjukkan bahwa usaha tersebut layak untuk dijalankan. Adapun kriteria kelayakan finansial usaha ini dilihat dari nilai NPV, IRR, Net B/C ratio, BEP, dan PP. Masing-masing nilai tersebut adalah NPV sebesar Rp 121.239.464 (NPV > 0), IRR sebesar 74\% (IRR > 24\%), Net B/C ratio sebesar 2,1 (B/C ratio > 1), BEP 71,31 kg dan PP selama 1 tahun 4 bulan 11 hari. Analisis sensitivitas pada usaha madu "Mekar Sari" menunjukkan bahwa, usaha masih layak untuk dijalankan meskipun terjadi perubahan pada biaya operasional dan pendapatan.

\section{SARAN}

1. Produk (Madu) "Mekar Sari” sebaiknya tidak hanya dipasarkan hanya berdasarkan permintaan konsumen, tetapi juga bisa dipasarkan ke luar daerah sehingga dapat meningkatkan pendapatan bagi peternak.

2. Usaha madu "Mekar Sari" sudah berdiri cukup lama dan masih bertahan hingga saat ini. Selain melakukan kegiatan budidaya lebah madu, peternak juga melakukan kegiatan penyuluhan dan bimbingan kepada masyarakat. Untuk ke depannya, diharapkan kepada peternak untuk tetap melakukan dan meningkatkan kegiatan penyuluhan dan bimbingan budidaya lebah madu tidak hanya kepada masyarakat setempat tetapi juga kepada masyarakat di daerah lainnya.

Analisis Kelayakan Finansial Budidaya Lebah Madu Di Desa Kuapan Kecamatan Tambang Kabupaten Kampar (Kasus Usaha Madu "Mekar Sari”) 


\section{DAFTAR PUSTAKA}

Adalina, Y. 2008. Analisis Finansial Usaha Lebah Madu (Apis mellifera, L). Jurnal Pendidikan Hutan dan Konservasi Alam. Vol. V, No 3. Hal 217-237.

Apriari Pramuka. 2010. Lebah Madu: Cara Beternak dan Pemanfaatan. Penebar Swadaya. Depok.

Djamin, Z. 1993. Perencanaan dan Analisa Proyek.

Gittinger, J.P. 1986. Analisa Ekonomi Proyek -proyek Pertanian. Universitas Indonesia. Jakarta.

Kuswadi. 2005. Meningkatkan Laba Perusahaan Melalui Pendekatan Akuntansi Keuangan dan Akuntansi Biaya. PT. Elex Media Komputindo. Jakarta.

Leonard, S. 2008. Analisis Biaya Usaha Madu Odeng di Desa Bantar Jaya, Kabupaten Bogor Jawa Barat. Skripsi. Institut Pertanian Bogor. Bogor.

Mulyadi. 1992. Akuntansi Biaya. Bagian Penerbitan STIE YKPN. Universitas Gadjah Mada. Yogyakarta.

Nurhasanah. 2007. Analisis Kelayakan Finansial Usaha Budidaya Lebah Madu Apis mellifera (Studi Kasus Peternakan Lebah Madu Sari Bunga di Desa Titisan Kecamatan Sukaraja Kabupaten Sukabumi). Institut Pertanian Bogor. Bogor.

Pramudya, B dan Dewi N. 1992. Ekonomi Teknik. Proyek Peningkatan Perguruan Tinggi. Institut Pertanian Bogor. Bogor.

Raiborn, C.A, dan Kinney, M.R. 2011. Akuntansi Biaya. Mitra Wacana Media. Jakarta.

Sihombing, D.T.H. 1997. Ilmu Ternak Lebah Madu. Gadjah Mada University Press. Yogyakarta.

50 Analisis Kelayakan Finansial Budidaya Lebah Madu Di Desa Kuapan Kecamatan Tambang Kabupaten Kampar (Kasus Usaha Madu "Mekar Sari”) 
Warisno. 1993. Cara Pemeliharaan Lebah Madu. Dalam: Desa Kita. No 31/th VII DK.

1996. Budidaya Lebah Madu. Kanisius. Yogyakarta. Madu "Mekar Sari") 